\title{
PENGEMBANGAN PERANGKAT PEMBELAJARAN BERDASARKAN PEMBELAJARAN BERBASIS MASALAH UNTUK MENINGKATKAN KEMAMPUAN KOMUNIKASI MATEMATIS SISWA SMP NEGERI 1 GUNUNG MALELA
}

\author{
Christa Voni Roulina Sinaga \\ Prodi Pendidikan Matematika FKIP UHN Pematangsiantar \\ christaunimed@gmail.com
}

\begin{abstract}
The aims of this research is: (1) describe the level of mastery learning and increasing students' mathematical communication ability with problem-based learning, (2) describe students' activity during the learing process with problem-based learning, and (3) describe students' response to the component during problem-based learning. This research is development research. The population of this research are all of students in SMP N 1 Gunung Malela, and the sample chosen is random with VII-3 and VII-4 with 32 students for each class. The instrument used consisted of a test mathematical communication ability of student in description form. The instrumen has been declared eligible validation and had coefisien reability pre-tes and pos-tes 0,81 and 0,62. The results of this research shown that: (1) the level of students' mastery learning mathematical communication ability in the classical is $87,50 \%$ while the increasing of students' mathematiucal communication abilityin first trial 2,73 increase to 3,05 in the second trial. The most increasing aspect from mathematical communication ability is drawing, (2) students' activity during learing process with problem based learning has on efektive criteria, and (3) students' response to the component during problem-based learning has a positive respons. The research suggests to use problem based learning as the alternative way for teacher to increase students mathematical communication abilities.
\end{abstract}

Keywords: Problem Based Learning, and Mathematical Communication Ability

\begin{abstract}
Abstrak. Tujuan penelitian ini adalah: (1) mendeskripsikan tingkat kemampuan komunikasi matematis siswa dalam pembelajaran berbasis masalah; (2) mendeskripsikan aktivitas aktif siswa selama proses pembelajaran dalam pembelajaran berbasis masalah dan (3) mendeskripsikan respon siswa terhadap komponen dalam proses pembelajaran berbasis masalah. Jenis penelitian ini adalah pengembangan. Populasi dalam penelitian ini adalah seluruh siswa SMP N 1 Gunung Malela, dan sampelnya dipilih secara acak yaitu VII-3 dan VII-4 yang masing- masing berjumlah 32 orang. Instrumen yang digunakan terdiri dari tes komunikasi matematik siswa yang berbentuk uraian. Instrumen tersebut dinyatakan telah memenuhi syarat validasi serta memiliki koefisien realibilitas pre-tes dan pos-tes 0,81 dan 0,62. Hasil penelitian menunjukkan bahwa: (1) tingkat ketercapaian kemampuan komunikasi matematis siswa dalam pembelajaran berbasis masalah yaitu secara klasikal sebesar $87,50 \%$ sedangkan peningkatan kemampuan komunikasi matematis siswa pada ujicoba I yaitu 2,73 meningkat menjadi 3,05 pada ujicoba II. Aspek kemampuan komunikasi matematis yang paling tinggi peningkatannya adalah pada aspek menggambar; (2) aktivitas aktif siswa selama proses pembelajaran dalam pembelajaran berbasis masalah sudah berada pada kriteria batasan keefektifan pembelajaran; dan (3) respon siswa terhadap komponen dalam proses pembelajaran berbasis masalah sudah menunjukkan respon yang positip.Peneliti menyarankan agar pembelajaran berbasis masalah menjadi alternatif bagi guru dalam meningkatkan kemampuan komunikasi matematis siswa.
\end{abstract}

Kata Kunci: Pembelajaran Berbasis Masalah dan Kemampuan Komunikasi Matematis 


\section{PENDAHULUAN}

Perubahan padigma dalam dunia pendidikan menuntut adanya perubahan pada tujuan pendidikan yang akan dicapai. Perubahan dalam tujuan pendidikan selanjutnya diimplementasikan terhadap kurikulum yang berlaku. Sanjaya (2011:4) menyatakan bahwa: "Dalam konsep kurikulum sebagai mata pelajaran biasanya erat kaitannya dengan usaha untuk memperoleh ijazah. Ijazah sendiri pada dasarnya menggambarkan kemampuan. Artinya, apabila siswa telah berhasil mendapatkan ijazah berarti dia telah menguasai pelajaran sesuai kurikulum yang berlaku. Kemampuan tersebut tercermin dalam nilai setiap mata pelajaran yang terkandung dalam ijazah itu. Siswa yang belum memiliki kemampuan atau belum memperoleh nilai berdasarkan standar tertentu tidak akan mendapat ijazah, walaupun mungkin saja mereka telah mempelajari kurikulum tersebut".

Implementasi kurikulum tahun 2013, melalui para guru yang mengarahkan siswa untuk mengusung paradigma belajar abad 21, diharapkan dapat membantu siswa untuk melakukan observasi, bertanya, bernalar, dan mengkomunikasikan apa yang diperoleh atau diketahuinya yang merupakan tujuan pendidikan nasional, yakni jabaran UUD 1945 tentang pendidikan dituangkan dalam Undang-undang No. 20 Tahun 2003 pasal 3 menyebutkan bahwa: "Pendidikan nasional berfungsi mengembangkan kemampuan dan membentuk watak serta peradaban bangsa yang bermartabat dalam rangka mencerdaskan kehidupan bangsa, bertujuan untuk berkembangnya potensi peserta didik agar menjadi manusia yang beriman dan bertakwa kepada Tuhan yang maha esa, berakhlak mulia, sehat, berilmu, cakap, kreatif, mandiri dan menjadi warga negara yang demokratis serta bertanggung jawab".

Hasbullah (2011:125) menyebutkan bahwa: "Setiap warga Negara mempunyai hak yang sama untuk memperoleh pendidikan yang bermutu, setiap warga negara berhak mendapatkan kesempatan meningkatkan pendidikan sepanjang hayat". Perubahan kurikulum matematika perlu memperhatikan beberapa hal yang saling mempengaruhi satu dengan lainnya, yaitu RPP (Rencana Pelaksanaan Pembelajaran), buku teks yang akan digunakan, tentu membutuhkan LAS (Lembar Aktif Siswa), prosedur penilaian yang digunakan dari kebijaksanaan yang dikeluarkan oleh pemerintah. Alice (Sanjaya 2011:71) menyarankan hal-hal sebagai berikut: "(1) Kurikulum harus disesuaikan dengan perkembangan anak, (2) Isi kurikulum mencakup ketrampilan, pengetahuan, dan sikap yang dianggap berguna untuk masa sekarang dan masa yang akan datang, (3) Anak hendaknya ditempatkan sebagai subjek belajar yang berusaha untuk belajar sendiri".

Artinya siswa harus didorong untuk melakukan berbagai aktivitas belajar, bukan hanya sekedar menerima informasi dari guru. Salah satu indikator yang menunjukkan mutu pendidikan matematika di Indonesia cenderung rendah adalah hasil penilaian Internasional mengenai prestasi belajar siswa khususnya matematika. Badan Penelitian dan Pengembangan (Litbangkemdikbud, 2011) melaporkan hasil survey Trends in Internasional Mathematics and Science Study (TIMSS) dan Programme for Internasional Students Assesment (PISA) sebagai berikut:

"Pada tahun 2003 menunjukkan prestasi belajar siswa SMP Indonesia berada di peringkat 34 dari 45 negara. Walaupun rerata skor naik 411 dibanding 403 pada tahun 1999, Indonesia masih berada dibawah rerata untuk wilayah ASEAN. Prestasi belajar siswa Indonesia pada TIMSS 2007 lebih memprihatinkan lagi, karena skor siswa turun menjadi 397, jauh lebih rendah dibandingkan rerata skor Internasional yaitu 500. Prestasi siswa pada TIMSS 2007 berada pada peringkat 
36 dari 49 negara. Bahkan hasil lebih buruk ditunjukkan dari hasil penelitian terbaru pada TIMSS 2011 yakni peringkat 39 dari 43 negara.

Pada PISA 2003, Indonesia berada di peringkat 38 dari 40 negara, dengan rerata skor 360. Pada tahun 2006 rerata skor naik menjadi 391, yaitu peringkat 50 dari 57 negara. Sedangkan pada tahun 2009, Indonesia hanya menempati peringkat 61 dari 65 negara dengan rerata skor 371, sementara rerata skor Internasional adalah 496, pada tahun 2013 Indonesia menempati peringkat 64 dari 65 negara dengan rerata skor 375 .

Hasil TIMMS dan PISA yang rendah terhadap prestasi belajar anak Indonesia tentunya disebabkan oleh banyak faktor".

NCTM (1989:7) merekomendasikan 5 kompetensi standar matematika yang utama yaitu: kemampuan pemecahan masalah ( problem solving), komunikasi (communication), koneksi (connection), penalaran (reasoning), representasi (representation). Salah satu dari lima standar proses prinsip-prinsip dan standar dari NCTM, yaitu komunikasi (Walle, 2007). Komunikasi biasa membantu pembelajaran siswa tentang konsep matematika baru ketika mereka memerankan situasi, menggambarkan, menggunakan objek, memberikan laporan dan penjelasan verbal. Juga ketika menggunakan diagram, menulis dan menggunakan simbol matematika. Kesalahpahaman biasa diidentifikasi dan ditunjukkan. Keuntungan sampingannya adalah bisa mengingatkan siswa bahwa mereka berbagi bertanggung jawab dengan guru atas pembelajaran yang muncul dalam pelajaran itu.

Dari prinsip-prinsip dan standar NCTM yang dikemukakan di atas, maka dapat dikatakan bahwa kemampuan komunikasi matematika merupakan hal yang sangat penting dan perlu ditingkatkan dalam pembelajaran matematika, untuk meningkatkan hasil belajar matematika. Aspek komunikasi melatih siswa untuk dapat mengkomunikasikan gagasannya, baik komunikasi lisan maupun komunikasi tulisan. Namun, pada kenyataannya setelah dilakukan observasi di SMP Negeri 1 Gunung Malela menunjukkan bahwa kemampuan komunikasi siswa masih rendah terlihat dari soal yang diberikan pada siswa yaitu: Seorang petani mempunyai sebidang tanah berbentuk persegi panjang. Lebar tanah tersebut $6 \mathrm{~m}$ lebih pendek daripada panjangnya. Jika keliling tanah $60 \mathrm{~m}$, a) buatlah model matematika dari keterangan diatas. b) tentukan luas tanah petani tersebut

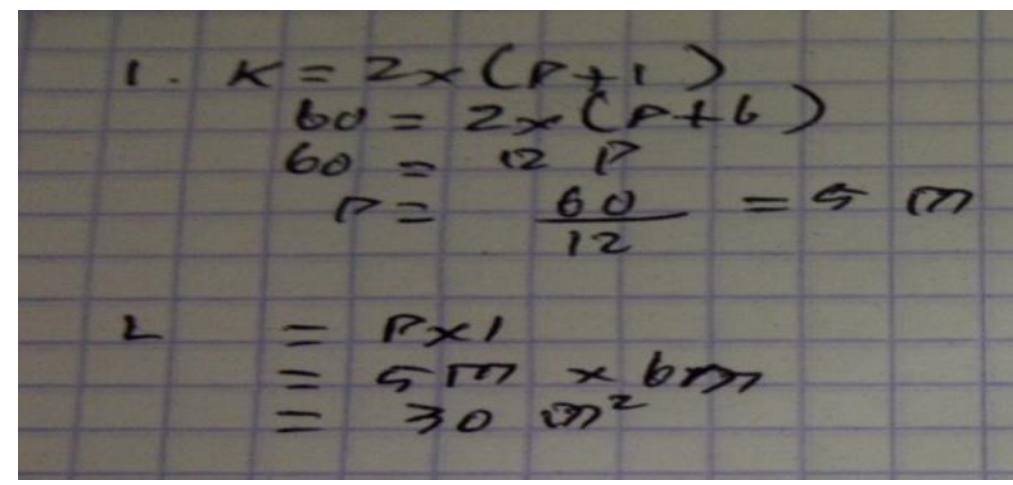

Gambar 1. Jawaban Kemampuan Komunikasi Matematis Siswa

Dari hasil analisis lembaran jawaban siswa di atas bahwa dari 35 siswa banyak siswa yang mengalami kesulitan dalam menjawab soal tersebut antaranya 5 siswa tidak mengetahui apa yang diketahui, 20 siswa sulit mengemukakan ide matematikanya 
secara tulisan, ditemukan kesalahan siswa dalam menafsirkan soal, menuliskan simbol dan menjawab dengan bahasa matematika serta jawaban yang disampaikan oleh siswa sering kurang terstruktur sehingga sulit dipahami oleh guru maupun temannya akibatnya kemampuan komunikasi matematika siswa rendah karena hasil pre-tes siswa rata-rata 50 atau 2 dengan predikat C. Hamalik (2001:90) menyatakan bahwa: "Tujuan siswa adalah meliputi minat yang ingin dipuaskan dan kegiatan-kegiatan yang ingin dilaksanakan oleh siswa, biasanya kelihatan dalam bentuk pertanyaan atau masalah yang timbul dalam diskusi”. Dalam memahami teorema dan rumus-rumus yang terdapat dalam buku teks membuat lemahnya pemahaman siswa terhadap konsepkonsep yang diberikan. Penggunaan kata-kata maupun kalimat yang sulit dipahami juga menjadi kendala tersendiri yang harus dihadapi siswa untuk memahami materi yang terdapat dalam buku teks. Permasalahan-permasalahan yang demikian menyebabkan siswa kurang berminat dalam mengkaji materi yang terdapat dalam buku teks. Akibatnya, ada atau tidak adanya buku teks tidak terlalu berpengaruh terhadap kemampuan siswa memahami materi pelajaran.

Berdasarkan Peraturan Pemerintah Nomor 65 tahun 2013 tentang standar proses pembelajaran, maka dapat dikatakan bahwa model pembelajaran yang sesuai dengan sasaran penilaian berbasis proses adalah sekolah yang menerapkan model pembelajaran berbasis konstruktivistik, antara lain model project-based learning, problem-based learning, discovery learning, cooperatif learning, contextual learning. Hal ini didukung oleh pernyataan Nur, bahwa kunci keberhasilan penggunaan asesmen berbasis kelas adalah melibatkan partisipasi Matematikasi siswa dalam proses pembelajaran dengan pendekatan scientific learning (Nur, 2008:4).

Pembelajaran dengan kurikulum 2013 senantiasa lebih diarahkan pada kegiatankegiatan yang dapat mendorong siswa untuk belajar aktif baik secara mental, fisik maupun sosial. Guru sebagai fasilitator, motivator dan mediator, memberikan kesempatan kepada siswa sehingga mereka dapat belajar seluas-luasnya serta membangun pengetahuannya sendiri. Untuk mencapai tujuan di atas perlu adanya model pembelajaran yang bisa mengatasi masalah pendidikan yang telah diungkapkan di atas, Istarani (2012:1) menyatakan bahwa: "Model pembelajaran adalah seluruh rangkaian penyajian materi ajar yang meliputi segala aspek sebelum, sedang dan sesudah pembelajaran yang dilakukan guru serta segala fasilitas yang terkait yang digunakan secara langsung atau tidak langsung dalam proses belajar mengajar". Yang dimaksud harus memiliki syarat antara lain dapat membuat siswa mampu mengonstruksi pengetahuan, dapat membuat siswa mandiri dalam belajar, dapat meningkatkan interaksi siswa, dapat melatih siswa untuk mengomunikasikan idenya dan dapat meningkatkan pengetahuan siswa memecahkan masalah. Dengan ciri-ciri yang dimiliki tersebut diharapkan model pembelajaran itu akan berakibat pada meningkatnya hasil belajar siswa. Dengan demikian dalam Nur (2008:30) menyatakan bahwa: "model pembelajaran yang sesuai adalah dengan menerapkan model pembelajaran berbasis masalah, dan penggunaanya untuk menumbuhkan dan mengembangkan berfikir tingkat tinggi dalam situasi-situasi berorientasi masalah, mencakup bagaimana belajar. Hasil belajar dengan pembelajaran berbasis masalah, dasar pengetahuan yang dapat diukur, keterampilan sosial dan etika, kemampuan bekerja sama dalam tim, dan keterampilan komunikasi".

Lebih lanjut, Saragih (2007) menyatakan bahwa: "keterampilan soft skill siswa seperti kemampuan bekerja sama, berkomunikasi, semangat dalam melakukan tugas, mengelola waktu, mengembangkan berfikir logis (keterampilan berfikir memecahkan 
masalah), dan menanamkan nilai moral, budi pekerti dan akhlak mulia dapat diajarkan dan dilatihkan dengan model pembelajaran berbasis masalah". Dalam pembelajaran berbais masalah siswa mampu mengembangkan keterampilan berfikir dan memecahkan masalah, sehingga siswa itu dengan sendirinya dapat menemukan bagaimana konsep itu terbentuk. Sesuai dengan pendapat Nur (2008:38) menyatakan bahwa: "pembelajaran berbasis masalah (problem-based learning) dirancang terutama untuk membantu siswa: (1) mengembangkan keterampilan berfikir, memecahkan masalah dan intelektual; (2) belajar peran-peran orang dewasa dengan menghayati peran-peran itu melalui situasi-situasi nyata atau yang disimulasikan; dan (3) belajar mandiri, maupun siswa otonom". Untuk dapat melaksanakan pembelajaran berbasis masalah diatas, maka perlu dikembangkan perangkat pembelajaran berbasis masalah yang baik sesuai dengan langkah-langkah dalam model pengembangan perangkat yang sesuai.

\section{METODE}

Penelitian ini dikategorikan ke dalam jenis penelitian pengembangan. Pengembangan perangkat pembelajaran tersebut berupa perancangan perangkat pembelajaran matematika materi persamaan dan pertidaksamaan linier satu variabel mulai dari Rencana Pelaksanaan Pembelajaran (RPP), Buku Guru (BG), Buku Siswa (BS), dan Lembar Aktivitas Siswa (LAS). Penelitian ini dilaksanakan di SMP Negeri 1 Gunung Malela Semester genap tahun pelajaran 2014/2015 pada materi persamaan dan pertidaksamaan linier satu variabel. Subjek dalam penelitian ini adalah siswa kelas VII SMP Negeri 1 Gunung Malela. Pengembangan perangkat pembelajaran dalam penelitian ini mengacu pada model pengembangan perangkat pembelajaran menurut Thiagarajan. Rancangan penelitian desain Pre-test and Post-test Group, dengan pola sebagai berikut:

\begin{tabular}{|lll|}
\hline $\mathrm{O}_{1}$ & $\mathrm{X}$ & $\mathrm{O}_{2}$ \\
\hline
\end{tabular}

dengan:

$\mathrm{O}_{1}:$ Uji awal (pre-test)

$\mathrm{X}$ : Perlakuan melalui pembelajaran berdasarkan masalah yang telah dikembangkan.

$\mathrm{O}_{2}$ : Uji akhir (post-test)

\section{HASIL DAN PEMBAHASAN \\ Hasil Ujicoba I}

Uji coba I dilakukan pada kelas VII-4 dengan banyak subjek ujicoba 32 orang. Pembelajaran pada kelas ini dilakukan sebanyak 4 kali pertemuan sesuai dengan rencana pembelajaran yang disediakan.

\section{Hasil Analisis Data Kemampuan Komunikasi Matematis Siswa}

Data kemampuan komunikasi matematis siswa diperoleh dari tes kemampuan komunikasi matematis siswa yang dilakukan du kali yaitu tes awal (pretes) dan tes akhir (postes). Berikut ini gambar dari pencapaian pretes dan postes kemampuan komunikasi matematis siswa materi persamaan dan pertidaksamaan linear satu variabel pada ujicoba I. 


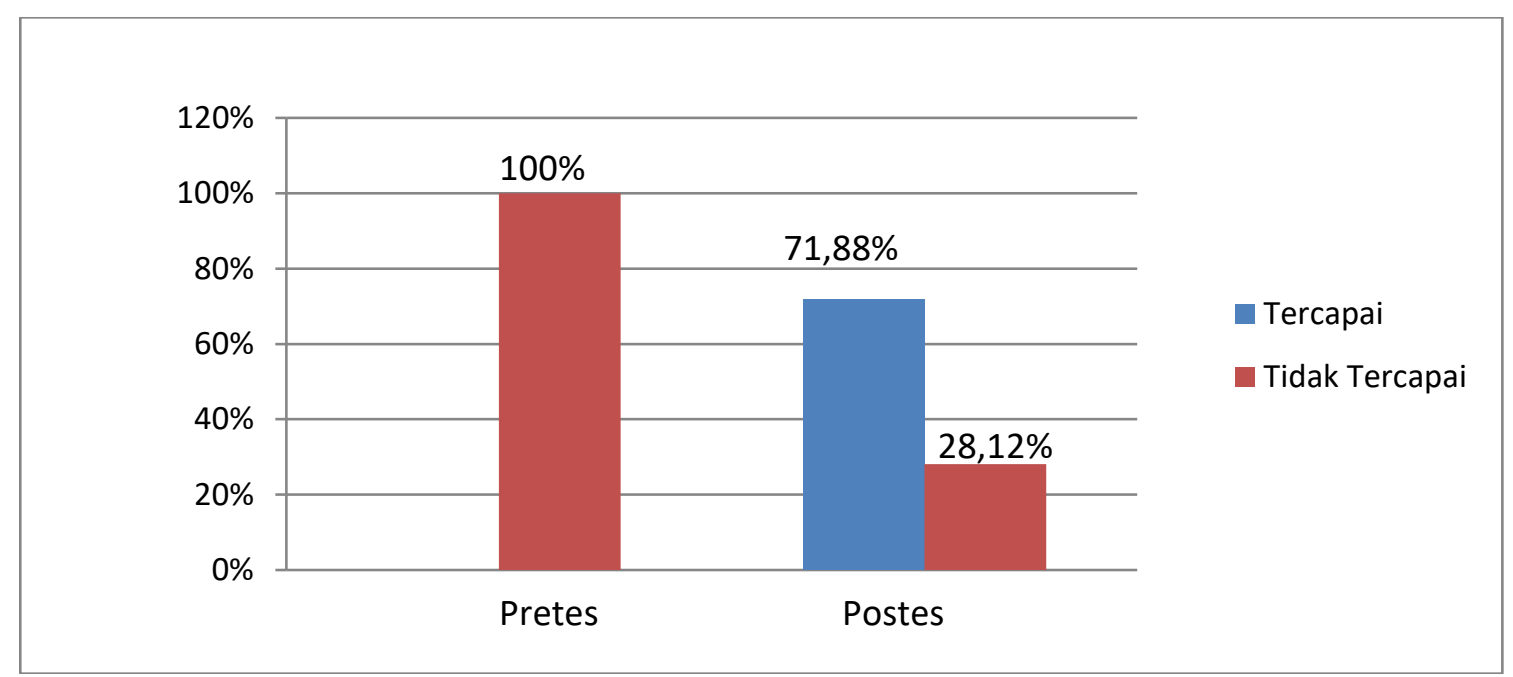

Gambar 2. Tingkat Pencapaian Kemampuan Komunikasi Matematis Siswa dalam Pretes dan Postes pada Ujicoba I

Berdasarkan penjelasan di atas, jumlah siswa yang telah memahami komunikasi matematis siswa pada topik persamaan dan pertidaksamaan linear satu variabel adalah sebanyak 23 orang $(71,88 \%)$ dari 32 orang siswa yang mengikuti postes kemampuan komunikasi matematis siswa. Jika persentase ini dirujuk pada kriteria yang ditetapkan pada bab III, dapat disimpulkan bahwa presentase siswa yang mampu memahami komunikasi matematis siswa belum tercapai. Berikut ini merupakan kondisi rata-rata kemampuan komunikasi matematis siswa pada ujicoba I untuk setiap aspek komunikasi matematis.

Tabel 1. Rata-Rata Setiap Aspek Kemampuan Komunikasi Matematis Siswa pada Ujicoba I

\begin{tabular}{cccc}
\hline (1) & (2) & \multicolumn{2}{c}{ (3) } \\
\hline \multirow{2}{*}{ Aspek komunikasi Matematis } & No & \multicolumn{2}{c}{ Rata-rata (Mean) } \\
\cline { 3 - 4 } & Soal & Pretes & Postes \\
\hline Menggambar & $1,2,3,4,5$ & 7,01 & 16,79 \\
\hline Membuat model & $1,2,3,4,5$ & 6,63 & 16,66 \\
\hline Menulis & $1,2,3,4,5$ & 8,09 & 17,82 \\
\hline Keseluruhan aspek & & $\mathbf{7 , 2 4}$ & $\mathbf{1 7 , 0 9}$ \\
\hline
\end{tabular}

Adapun rata-rata kemampuan komunikasi matematis pada ujicoba I dapat digambarkan pada Gambar 3 berikut ini: 


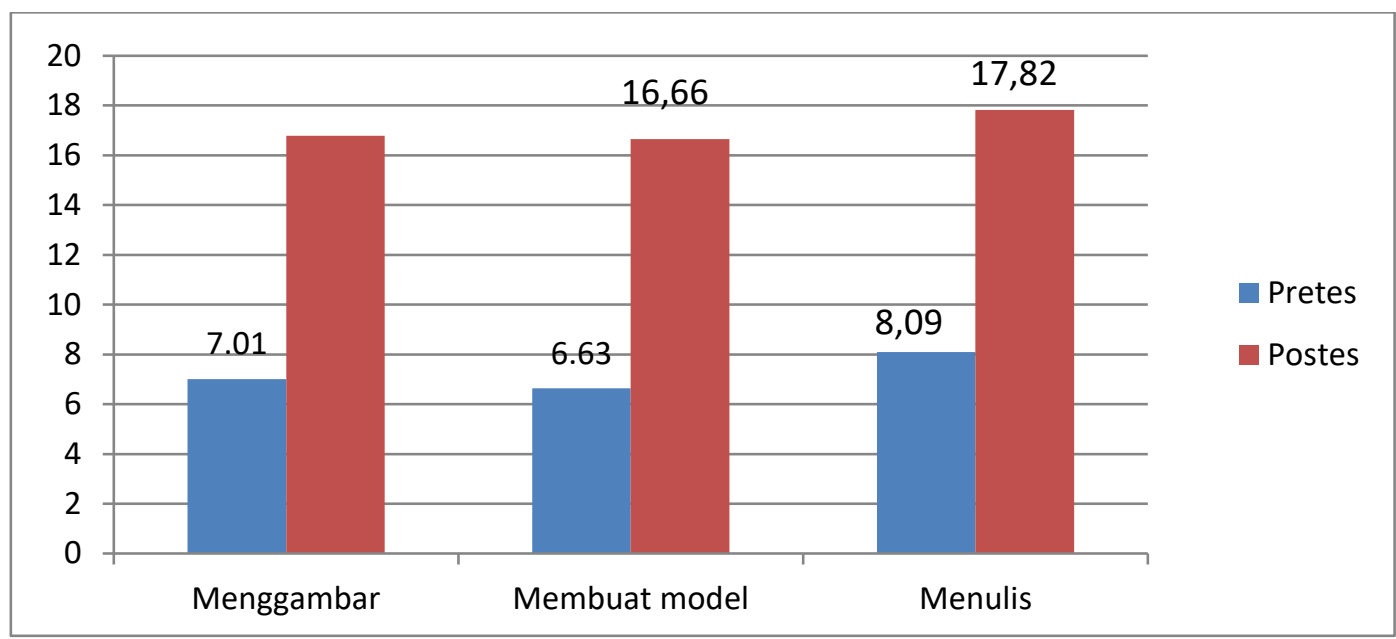

Gambar 3. Rata-rata Aspek Kemampuan Komunikasi Matematis pada Ujicoba I

Dari Tabel 1 dan Gambar 3 di atas dari rata-rata kemampuan komunikasi matematis menunjukkan bahwa terdapat peningkatan pada setiap aspek komunikasi. Siswa mengalami peningkatan kemampuan komunikasi matematis pada aspek menggambar dengan rata-rata pada pretes $(7,01)$ sedangkan postes $(16,79)$, kemudian pada aspek membuat model dengan rata-rata pretes $(6,63)$ sedangkan postes $(16,66)$, dan pada aspek menulis dengan rata-rata pretes $(8,09)$ sedangkan postes $(17,82)$. Terlihat bahwa dari rata-rata kemampuan komunikasi matematis menunjukkan bahwa terdapat peningkatan pada setiap aspek komunikasi.

\section{Hasil Analisis Data Aktivitas Siswa}

Aktivitas siswa diamati oleh dua orang pengamat. Pengamatan dilakukan selama proses pembelajaran berlangsung dan hasilnya dapat dilihat pada tabel berikut:

Tabel 2. Aktivitas Siswa Selama Pembelajaran (Uji coba I)

\begin{tabular}{|c|c|c|c|c|c|c|}
\hline \multirow[t]{2}{*}{ No } & \multirow[t]{2}{*}{ Kategori Pengamatan } & \multicolumn{4}{|c|}{$\begin{array}{c}\text { Persentase Waktu Ideal } \\
\text { Aktivitas Siswa dalam } \\
\text { Pembelajaran }(\%) \text { pada } \\
\text { pertemuan } \\
\end{array}$} & \multirow[t]{2}{*}{$\begin{array}{c}\text { Kriteria } \\
\text { Batasan } \\
\text { Keefektifan } \\
(\%) \\
\end{array}$} \\
\hline & & 1 & 2 & 3 & 4 & \\
\hline 1 & $\begin{array}{l}\text { Memperhatikan/mendengarkan } \\
\text { penjelasan guru/teman }\end{array}$ & 15,20 & 14,17 & 11,33 & 14,17 & $9-19$ \\
\hline 2 & $\begin{array}{lr}\begin{array}{l}\text { Membaca/memahami } \\
\text { kontekstual dalam } \\
\text { siswa/LKS }\end{array} & \text { buku } \\
\end{array}$ & 13,13 & 12,83 & 12,50 & 12,83 & $6-16$ \\
\hline 3 & $\begin{array}{l}\text { Menyelesaikan } \\
\text { masalah/menemukan cara dan } \\
\text { jawaban masalah }\end{array}$ & 36,67 & 38,67 & 40,17 & 38,67 & $33-43$ \\
\hline 4 & $\begin{array}{l}\text { Berdiskusi/bertanya kepada teman } \\
\text { atau guru }\end{array}$ & 21,33 & 21,50 & 22,33 & 21,50 & $19-29$ \\
\hline 5 & $\begin{array}{lll}\text { Menarik kesimpulan } & \text { suatu } \\
\text { Prosedur atau konsep } & \\
\end{array}$ & 12,83 & 12,83 & 13,67 & 12,83 & $8-18$ \\
\hline 6 & $\begin{array}{l}\text { Perilaku yang tidak relevan } \\
\text { dengan KBM }\end{array}$ & 0,67 & 0,00 & 0,00 & 0,00 & $0-5$ \\
\hline
\end{tabular}

Dari Tabel 2 dapat dianalisis bahwa untuk setiap pertemuan aktivitas siswa 
berada pada kriteria batasan keefektifan pembelajaran seperti yang diuraikan pada BAB III. Karena persentase aktivitas siswa untuk tiap kategori pengamatan dan tiap pertemuan berada pada kriteria batasan keefektifan pembelajaran, maka perangkat pembelajaran tidak mengalami revisi berdasarkan hasil pengamatan aktivitas siswa.

\section{Analisis Data Hasil Angket Respon Siswa}

Respon siswa terhadap pembelajaran meliputi respon positif dan respon negatif. Respon positif diketahui dari pernyataan siswa senang, baru dan berminat terhadap komponen dan kegiatan pembelajaran. Respon negatif adalah pernyataan siswa menyatakan tidak senang, tidak baru, dan tidak berminat terhadap komponen dari kegiatan pembelajaran. Hasil analisis dat respon siswa terhadap komponen dan kegiatan pembelajaran disajikan pada tabel 3 berikut:

Tabel 3. Hasil Angket Respon Siswa Ujicoba I

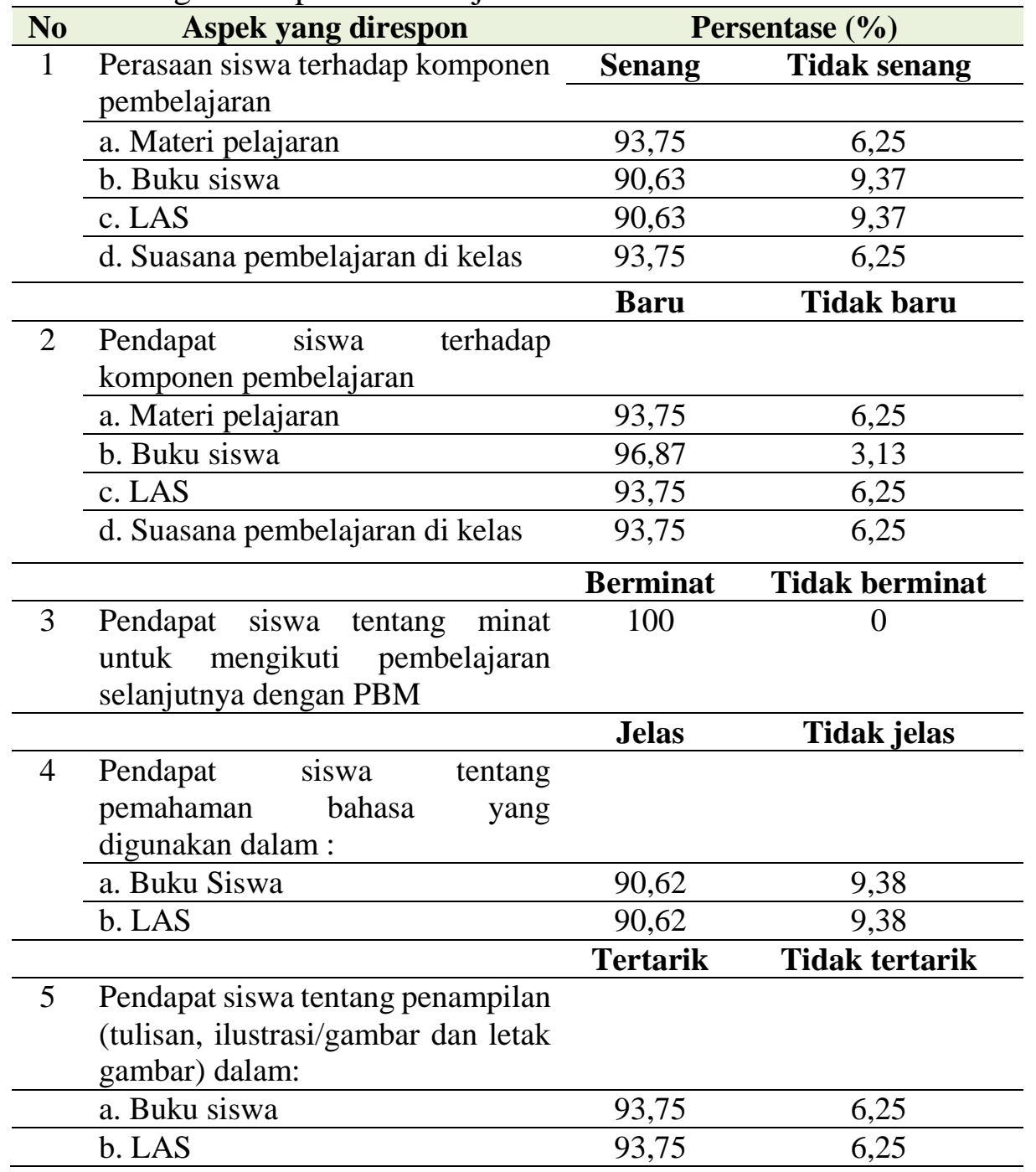

Berdasarkan data pada tabel 3 di atas diperoleh persentase banyak siswa yang menyatakan sangat menarik terhadap komponen dan kegiatan pembelajaran, yaitu: $93,75 \%, 90,63 \%, 90,63 \%$, dan 93,75\%. Persentase siswa yang menyatakan senang terhadap materi pelajaran adalah $93,75 \%$. Persentase ini diperoleh dari hasil bagi banyak siswa yang menyatakan senang terhadap materi pelajaran (sebanyak 30 orang 
siswa) dengan banyak siswa yang mengisi angket (sebanyak 32 orang) dikali $100 \%$. Dengan cara yang sama diperoleh persentase jawaban siswa yang menyatakan senang terhadap komponen dan kegiatan pembelajaran yang lain.

Selanjutnya persentase banyak siswa yang menyatakan komponen dan kegiatan pembelajaran masih baru, yaitu: 93,75\%, 96,87\%, 93,75\%, dan 93,75\%. Persentase siswa menyatakan baru terhadap materi pelajaran adalah 93,75\%. Persentase ini diperoleh dari hasil bagi banyak siswa yang menyatakan baru terhadap materi pelajaran (sebanyak 30 orang siswa) dengan banyak siswa yang engisi angket (sebanyak 32 orang) dikali $100 \%$. Dengan cara yang sama diperoleh persentase jawaban siswa menyatakan baru terhadap komponen dan kegiatan pembelajaran yang lain. Persentase banyak siswa yang menyatakan berminat untuk mengikuti pembelajaran selanjutnya dengan PBM adalah $100 \%$, persentase banyak siswa yang menyatakan jelas tentang bahasa yang digunakan dalam BS dan LAS masing-masing 90,62\%. Selanjutnya persentase banyak siswa yang menyatakan tertarik terhadap penampilan tulisan/ilustrasi gambar dalam BS dan LAS, masingmasing adalah $93,75 \%$.

Dari data di atas, dapat dianalisis bahwa respon siswa terhadap semua aspek komponen dan kegiatan pembelajaran di atas $80 \%$. Jika hasil analisis ini dirujuk pada kriteria yang ditetapkan pada bab III, dapat disimpulkan bahwa respon siswa terhadap komponen dan kegiatan pembelajaran dengan menggunakan perangkat pembelajaran berorientasi pada PBM adalah positf. Kesimpulan dari hasil analisis data ujicoba I sebagai berikut: (1) terdapat peningkatan peningkatan kemampuan komunikasi matematis siswa; (2) kemampuan komunikasi matematis siswa pada materi persamaan dan pertidaksamaan linear satu variabel dengan menggunakan pembalajaran berbasis masalah di kelas VII-4 belum mencapau kriteria yang ditentukan; (3) kadar aktivitas aktif siswa belum tercapai criteria keefektifannya; (4) angket respon siswa pada setiap komponen dan kegiatan pembelajaran adalah positif. Berdasarkan kesimpulan di atas, ada beberapa indikator keefektifan yang belum mencapai kriteria yang ditetapkan oleh karena itu perlu melakukan peninjauan ulang terhadap perangkat pembelajaran yang dikembanngkan.

\section{Hasil Ujicoba II}

Peranglat pembelajaran dan instrument penelitian yang telah diujicobakan di kelas VII-4 belum memenuhi kriteria keefektifan yang ditetapkan pada bab III sebelumnya. Oleh karena itu kegiatan selanjutnya adalah melakukan ujicoba ulang (ujicoba II) dengan memperhatikan indikator aspek keefektifan pembelajaran yang belum terpenuhi. Ujicoba II dilakukan dikelas VII-3 dengan banyak subjek ujicoba 32 orang siswa. Hasil analisis data ujicoba II diuraikan sebagai berikut:

\section{Hasil Analisis Data Kemampuan Komunikasi Matematis Siswa}

Data kemampuan komunikasi matematis siswa yang dilakukan dua kali yaitu tes awal (pretes) dan tes akhir (postes). Berikut ini gambar 4 dari pencapaian pretes dan postes kemampuan komunikasi matematis siswa materi persamaan dan pertidaksamaan linear satu variabel pada ujicoba II. 


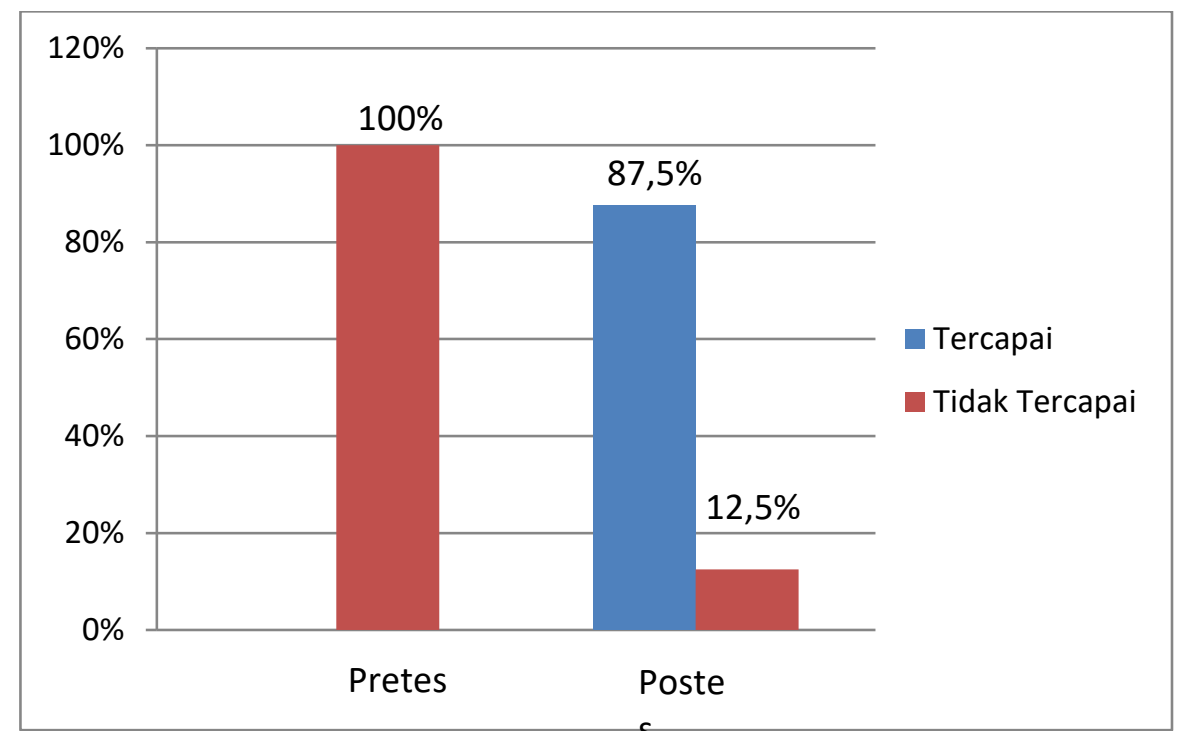

Gambar 4. Tingkat Pencapaian Kemampuan Komunikasi Matematis Siswa dalam Pretest dan Posttest pada Ujicoba II

Berdasarkan penjelasan di atas, jumlah siswa yang telah memahami komunikasi matematis siswa pada topik persamaan dan pertidaksamaan linear satu variabel adalah sebanyak 28 orang $(87,50 \%)$ dari 32 orang siswa yang mengikuti postes kemampuan komunikasi matematis siswa. Jika persentase ini dirujuk pada kriteria yang ditetapkan, dapat disimpulkan bahwa persentase siswa yang mampu memahami komunikasi matematis siswa sudag mencapai persentase yang ditetapkan. Perbandingan hasil postes siswa yang telah memahami komunikasi matematis siswa pada materi persamaan dan pertidaksamaan linear satu variabel pada ujicoba I dan ujicoba II dapat dilihat ada Tabel 4 berikut ini.

Tabel 4. Perbandingan Hasil Postes Kemampuan Komunikasi Matematis Siswa

\begin{tabular}{ccc}
\hline Postes & $\begin{array}{c}\text { Persentase (\%) Siswa yang } \\
\text { telah memahami komunikasi } \\
\text { matematis }\end{array}$ & $\begin{array}{c}\text { Persentase (\%) Siswa yang } \\
\text { belum memahami } \\
\text { komunikasi matematis }\end{array}$ \\
\hline Ujicoba I & $\mathbf{7 1 , 8 8}$ & $\mathbf{2 8 , 1 2}$ \\
\hline Ujicoba II & $\mathbf{8 7 , 5 0}$ & $\mathbf{1 2 , 5 0}$ \\
\hline
\end{tabular}

Berikut ini gambar 5 dari pencapaian prettest dan postest kemampuan komunikasi matematis siswa materi persamaan dan pertidaksamaan linear satu variabel pada ujicoba I dan II 


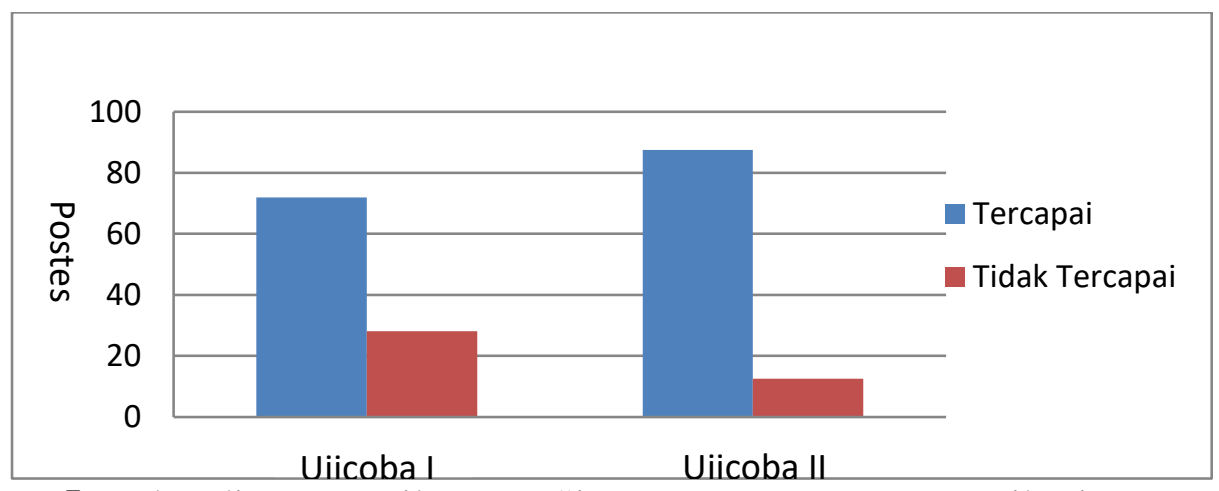

Gambar 5. Perbandingan Hasil Postes Siswa Kemampuan Komunikasi Matematis Siswa

Berdasarkan tabel 4 dan gambar 5 di atas, persentase siswa yang telah memahami komunikasi matematis siswa pada hasil ujicoba I adalah sebesar 71,88\% dan pada ujicoba II adalah sebesar $87,50 \%$. Hal ini menunjukkan bahwa persentase siswa yang telah memahami komunikasi matematis siswa pada materi persamaan dan pertidaksamaan linear satu variabel mengalami peningkatan sebesar $15,62 \%$. Berikut ini merupakan kondisi rata-rata kemampuan komunikasi matematis siswa pada penelitian untuk setiap aspek komunikasi matematis.

Tabel 5. Rata-Rata Setiap Aspek Kemampuan Komunikasi Matematis Siswa pada Ujicoba II

\begin{tabular}{cccc}
\hline \multirow{2}{*}{ Aspek komunikasi Matematis } & \multirow{2}{*}{ No. Soal } & \multicolumn{2}{c}{ Rata-rata (Mean) } \\
\cline { 3 - 4 } & & Pretes & Postes \\
\hline Menggambar & $2,3,4,5$ & 7,95 & 18,88 \\
\hline Membuat model & $1,2,3,4,5$ & & 19,29 \\
\hline Menulis & & 7,66 & 19,10 \\
\hline Keseluruhan aspek & $1,2,3,4,5$ & 8,15 & 19,09 \\
\hline
\end{tabular}

Adapun rata-rata kemampuan komunikasi matematis pada ujicoba II dapat digambarkan pada gambar 6 berikut ini:

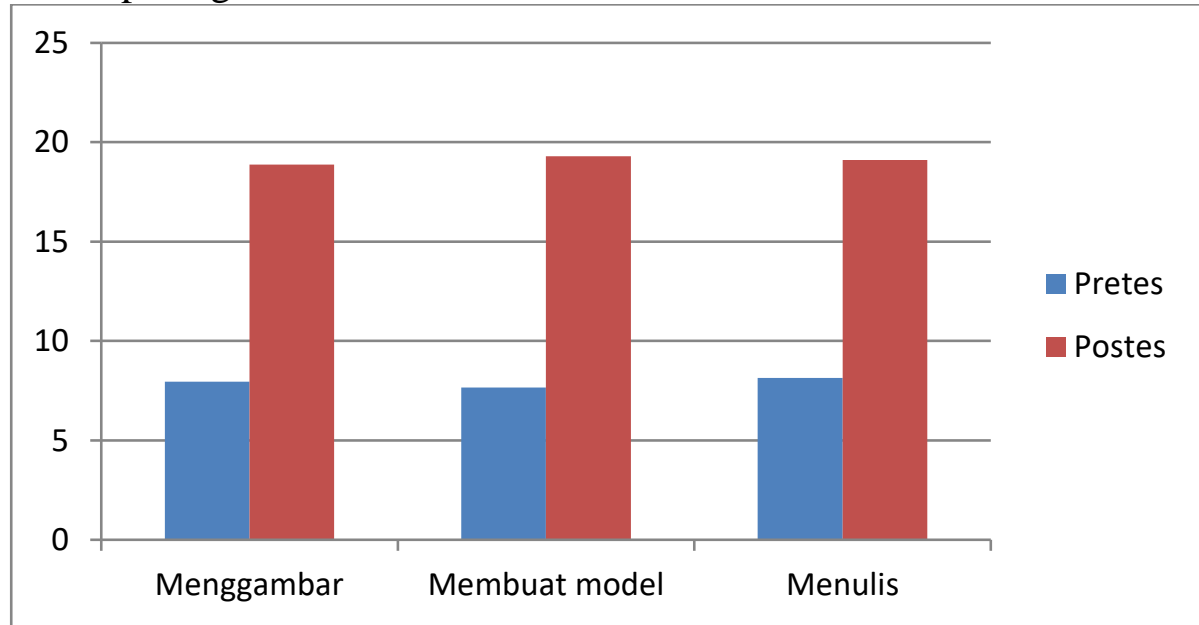

Gambar 6. Rata-rata Aspek Kemampuan Komunikasi Matematis pada Uji Coba II 
Tabel 5 dan Gambar 6 diatas dari rata-rata kemampuan komunikasi matematis menunjukkan bahwa terdapat peningkatan pada setiap aspek komunikasi. Siswa mengalami peningkatan kemampuan komunikasi matematis pada aspek menggambar dengan rata-rata pada pretes $(7,95)$ sedangkan postes $(18,88)$, kemudian pada aspek membuat model dengan rata-rata pretes $(7,66)$ sedangkan postes $(19,29)$, dan pada aspek menulis dengan rata-rata pretes $(8,15)$ sedangkan postes $(19,10)$. Terlihat bahwa dari rata-rata kemampuan komunikasi matematis menunjukkan bahwa terdapat peningkatan pada setiap aspek komunikasi.

\section{Hasil analisis data aktivitas siswa}

Perhitungan penentuan rerata dari persentase rerata frekuensi untuk masingmasing kategori pengamatan aktivitas siswa disajikan sebagai berikut:

Tabel 6. Aktivitas Siswa Selama Pembelajaran (Uji coba II)

\begin{tabular}{|c|c|c|c|c|c|c|}
\hline \multirow[t]{2}{*}{ No } & \multirow[t]{2}{*}{ Kategori Pengamatan } & \multicolumn{4}{|c|}{$\begin{array}{l}\text { Persentase Waktu Ideal } \\
\text { Aktivitas Siswa dalam } \\
\text { Pembelajaran }(\%) \text { pada } \\
\text { pertemuan }\end{array}$} & \multirow[t]{2}{*}{$\begin{array}{c}\text { Kriteria } \\
\text { Batasan } \\
\text { Keefektifan } \\
\quad(\%)\end{array}$} \\
\hline & & 1 & 2 & 3 & 4 & \\
\hline 1 & $\begin{array}{l}\text { Memperhatikan/mendengarkan } \\
\text { penjelasan guru/teman }\end{array}$ & 15,00 & 14,17 & 11,33 & 11,71 & $9-19$ \\
\hline 2 & 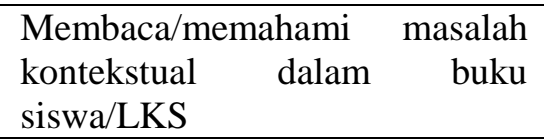 & 13,17 & 12,83 & 12,50 & 12,83 & $6-16$ \\
\hline 3 & $\begin{array}{l}\text { Menyelesaikan } \\
\text { masalah/menemukan cara dan } \\
\text { jawaban masalah }\end{array}$ & 37,00 & 38,67 & 40,17 & 38,67 & $33-43$ \\
\hline 4 & $\begin{array}{l}\text { Berdiskusi/bertanya kepada } \\
\text { teman atau guru }\end{array}$ & 21,67 & 21,50 & 22,33 & 21,50 & $19-29$ \\
\hline 5 & $\begin{array}{l}\text { Menarik kesimpulan suatu } \\
\text { Prosedur atau konsep }\end{array}$ & 12,83 & 12,83 & 13,67 & 12,83 & $8-18$ \\
\hline 6 & $\begin{array}{lll}\text { Perilaku yang tidak relevan } \\
\text { dengan KBM }\end{array}$ & 0,00 & 0,00 & 0,00 & 0,00 & $0-5$ \\
\hline
\end{tabular}

Dari Tabel 6 dapat dianalisis bahwa untuk setiap pertemuan aktivitas siswa berada pada kriteria batasan keefektifan pembelajaran. Karena persentase aktivitas siswa untuk tiap kategori pengamatan dan tiap pertemuan berada pada kriteria batasan keefektifan pembelajaran, maka perangkat pembelajaran tidak mengalami revisi berdasarkan hasil pengamatan aktivitas siswa.

Analisis data hasil angket respon siswa

Hasil analisis data respon siswa terhadap komponen dan kegiatan pembelajaran disajikan pada tabel berikut.

Tabel 7. Hasil Angket Respon Siswa Ujicoba II

\begin{tabular}{|c|c|c|c|}
\hline No. & Aspek yang direspon & \multicolumn{2}{|c|}{ Persentase $(\%)$} \\
\hline \multirow{3}{*}{1} & & Senang & Tdk senang \\
\hline & $\begin{array}{l}\text { Perasaan siswa terhadap komponen } \\
\text { pembelajaran }\end{array}$ & & \\
\hline & a. Materi pelajaran & 93,75 & 6,25 \\
\hline
\end{tabular}




\begin{tabular}{|c|c|c|c|}
\hline \multirow[t]{4}{*}{ No. } & \multirow{2}{*}{$\begin{array}{ll} & \text { Aspek yang direspon } \\
\text { b. Buku siswa }\end{array}$} & \multicolumn{2}{|c|}{ Persentase $(\%)$} \\
\hline & & 90,62 & 9.38 \\
\hline & c. LAS & 90,62 & 9,38 \\
\hline & d. Suasan pembelajaran di kelas & 96,87 & 3,13 \\
\hline \multirow{6}{*}{2} & & Baru & Tidak baru \\
\hline & $\begin{array}{l}\text { Pendapat siswa terhadap komponen } \\
\text { pembelajaran }\end{array}$ & & \\
\hline & a. Materi pelajaran & 93,75 & 6,25 \\
\hline & b. Buku siswa & 90,62 & 9,38 \\
\hline & c. LAS & 90,62 & 9,38 \\
\hline & d. Suasan pembelajaran di kelas & 96,87 & 3,13 \\
\hline \multirow{3}{*}{3} & & Berminat & Tdk berminat \\
\hline & $\begin{array}{l}\text { Pendapat siswa tentang minat untuk mengikuti } \\
\text { pembelajaran selanjutnya dengan PBM }\end{array}$ & 100,00 & 0,00 \\
\hline & & Jelas & Tidak jelas \\
\hline \multirow{4}{*}{4} & $\begin{array}{l}\text { Pendapat siswa tentang pemahaman bahasa yang } \\
\text { digunakan dalam: }\end{array}$ & & \\
\hline & a. Buku siswa & 90,62 & 9,38 \\
\hline & b. LAS & 90,62 & 9,38 \\
\hline & & Tertarik & $\begin{array}{c}\text { Tidak } \\
\text { tertarik }\end{array}$ \\
\hline \multirow[t]{3}{*}{5} & $\begin{array}{l}\text { Pendapat siswa tentang penampilan } \\
\text { (tulisan,ilustrasi/gambar dan letak gambar) } \\
\text { dalam: }\end{array}$ & & \\
\hline & a. Buku siswa & 93,75 & 6,25 \\
\hline & b. LAS & 93,75 & 6,25 \\
\hline
\end{tabular}

Berdasarkan data pada tabel 7 di atas, diperoleh persentase banyak siswa yang menyatakan sangat senang terhadap komponen dan kegiatan pembelajaran, yaitu: $93,75 \%, 90,62 \%, 90,62 \%$, dan 96,88\%. Persentase siswa menyatakan senang terhadap materi pelajaran adalah 93,75\%. Persentase ini diperoleh dari hasil bagi banyak siswa yang menyatakan senang terhadap materi pelajaran (sebanyak 30 orang siswa) dengan banyak siswa yang mengisi angket (sebanyak 32 orang siswa) dikali 100\%. Dengan cara yang sama diperoleh persentase jawaban siswa menyatakan senang terhadap komponen dan kegiatan pembelajaran yang lain.

Selanjutnya persentase banyak siswa yang menyatakan komponen dan kegiatan pembelajaran masih baru, yaitu: $93,75 \%, 90,62 \%, 90,62 \%$, dan 96,88\%. Persentase siswa menyatakan baru terhadap materi pelajaran adalah 93,75\%. Persentase ini diperoleh dari hasil bagi banyak siswa yang menyatakan baru terhadap materi pelajaran (sebanyak 30 orang siswa) dengan banyak siswa yang mengisi angket (sebanyak 32 orang) dikali $100 \%$. Dengan cara yang sama diperoleh persentase jawaban siswa menyatakan baru terhadap komponen dan kegiatan pembelajaran yang lain. Persentase banyak siswa yang menyatakan berminat untuk mengikuti pembelajaran selanjutnya dengan PBM adalah 100\%, persentase banyak siswa yang menyatakan jelas tentang bahasa yang digunakan dalam BAS dan LAS masing-masing adalah 90,62\%. Selanjutnya persentase banyak siswa yang menyatakan tertarik terhadap penampilan tulisan/ilustrasi gambar dalam BAS dan LAS, masing-masing adalah $93,75 \%$. 
Dari data di atas, dapat dianalisis bahwa respon siswa terhadap semua aspek komponen dan kegiatan pembelajaran berada di atas $80 \%$. Jika hasil analisis ini dirujuk pada kriteria yang ditetapkan pada, dapat disimpulkan bahwa respon siswa terhadap komponen dan kegiatan pembelajaran dengan menggunakan perangkat pembelajaran berorientasi pada model PBM adalah positif.

Kesimpulan dari hasil analisis data ujicoba II adalah sebagai berikut: (1) terdapat peningkatan kemampuan komunikasi matematis siswa; (2) kadar aktivitas aktif siswa mencapai kriteria keefektifan; (3) angket respon siswa pada setiap komponen dan kegiatan pembelajaran adalah positif. Jika kesimpulan hasil analisis data pada ujicoba II ini dirujuk pada kriteria yang ditetapkan, maska dapat disimpulkan bahwa penerapan produk perangkat pembelajaran yang dikembangkan telah memenuhi kriteria keefektifan.

\section{KESIMPULAN}

Pengembangan perangkat pembelajaran berdasarkan pembelajaran berbasis masalah menggunakan model pengembangan Thiagarajan, Semmel and Semmel ini bertujuan untuk meningkatkan komunikasi matematis siswa SMP Negeri 1 Gunung Malela. Berdasarkan rumusan masalah maka diperoleh perangkat pembelajaran yang valid dan efektif. Dengan demikian kesimpulan dalam penelitian ini disimpulkan sebagai berikut:

1. Validitas perangkat pembelajaran yang dikembangkan berdasarkan pembelajaran berbasis masalah untuk meningkatkan komunikasi matematis siswa berada pada kategori valid. Validitas instrument tes kemampuan komunikasi matematis siswa dipilih 5 soal yang memenuhi kriteriavalid secara isi maupun konstruk.

2. Keefektifan perangkat pembelajaran berdasarkan pembelajaran berbasis masalah untuk meningkatkan komunikasi matematis siswa telah memenuhi kriteria efektif, adapun kriterianya yaitu:

a. Ketercapaian kemampuan komunikasimatematis siswa dalam pembelajaran berbasis masalah secara klasikal yaitu apabila lebih dari atau sama dengan $80 \%$ siswa dikelas telah mendapat kemampuan predikat B (Nilai 2,67). Pada posttest uji coba II ketercapaian kemampuan komunikasi matematis siswa secara klasikal telah mencapai $87,50 \%$ yaitu 28 orang siswa dan 4 orang siswa yang tidak tercapai $(12,50 \%)$. Sehingga kriteria ini dapat dikatakan telah tercapai.

b. Aktivitas aktif siswa selama proses pembelajaran telah memenuhi batas toleransi persentase waktu ideal yaitu aktivitas membaca/memahami masalah kontekstual dalam buku siswa/LAS sebesar $12,83 \%$ dengan toleransi waktu ideal $6 \% \leq P W I 16 \%$, aktivitas menyelesaikan masalah/menemukan cara dan jawaban masalah sebesar 38,67\% dengan toleransi waktu ideal $33 \% \leq P W I \leq 43 \%$, aktivitas berdiskusi/bertanya kepada teman atau guru sebesar 21,50 dengan toleransi waktu ideal $19 \% \leq P W I \leq 29 \%$, aktivitas menarik kesimpulan suatu prosedur atau konsep sebesar 12,83 dengan toleransi waktu ideal $8 \% \leq P W I \leq 18 \%$, aktivitas perilaku yang tidak relevan dengan KBM sebesar 0,00 dengan toleransi waktu ideal $0 \% \leq P W I \leq 5 \%$.

c. Respon siswa terhadap komponen dan proses pembelajaran berbasis masalah dikatakan positif apabila lebih dari atau sama dengan $80 \%$ respon siswa berada pada kategori senang, baru dan berminat. Pada uji coba II respon siswa memenuhi kriteria minimal tinggi sebesar $90,62 \%$. Sehingga pada kategori ini 
dapat dikatakan bahwa Respon siswa terhadap komponen dan proses pembelajaran berbasis masalah secara klasikal berada pada kategori positif.

3. Kemampuan komunikasi matematis siswa berdasarkan pembelajaran berbasis masalah mengalami peningkatan dari posttest uji coba I ke posttes uji coba II. Hal ini dapat dilihat persentase ketercapaian secara klasikal dan nilai rata-rata indicator kemampuan komunikasi matematis siswa dari uji coba I ke uji coba II.

a. Tingkat ketercapaian kemampuan komunikasi matematis siswa secara klasikal pada saat posttes uji coba I sebesar 71,88\% meningkat menjadi $87,50 \%$ pada saat posttest uji coba II. Dengan demikian peningkatan kemampuan komunikasi matematis siswa secara klasikal dari uji coba I ke uji coba II adalah $15,62 \%$.

b. Nilai rata-rata indikator kemampuan komunikasi matematis siswa aspek menggambar pada saat uji coba I adalah 16,79 meningkat menjadi 19,88 pada uji coba II, indikator membuat model pada uji coba I adalah 16,66 meningkat menjadi 18,88 pada uju coba II, dan indikator menulis pada uji coba I adalah 17,82 meningkat menjadi 19,10 pada uji coba II. Dengan demikian peningkatan kemampuan komunikasi matematis siswa dilihat dari rata-rata indikator kemampuan komunikasi matematis siswa dari uji coba I ke uji coba II pada indikator menggambar 2,5, indikator membuat model 2,22, dan indikator menulis 1,28 .

\section{DAFTAR PUSTAKA}

Hamalik. 2001. Proses Belajar Mengajar. Bandung. Penerbit Bumi Aksara.

Hasbullah. 2011. Dasar-dasar Ilmu Pendidikan. Edisi revisi. Jakarta. Raja Grafindo Persada.

Istarani. 2012. 58 Model Pembelajaran Inovatif. Medan: Media Persada.

Litbangkemdikbud. 2011. Survei International TIMSS dan PISA. http://litbangkemdikbud.go.id.

NCTM. 1989. Curriculum and Evaluation Standards for School Mathematics. Reston, VA: NCTM

Nur, M. 2008. Model Pembelajaran Berdasarkan Masalah. Surabaya: PSMS Unesa. Sanjaya, W. 2011. Kurikulim dan Pembelajaran. Jakarta. Prenada Media Grup

Saragih, S. 2007. Mengembangkan Kemampuan Berpikir Logis dan Komunikasi Matematika Siswa SMP melalui Pendekatan Matematika Realistik. Pascasarjana Universitas Pendidikan Bandung; Disertasi (Tidak diterbitkan). 